\title{
Marine ecosystems and living resources in the Central Mediterranean Sea: an introduction
}

\author{
Angelo Bonanno 1 - Salem Wniss Zgozi - Othman Jarboui - Roberta Mifsud • \\ Luca Ceriola $\cdot$ Gualtiero Basilone $\cdot$ Enrico Arneri
}

Received: 31 May 2018/ Accepted: 14 June 2018/Published online: 10 July 2018

(C) Springer International Publishing AG, part of Springer Nature 2018

\section{Introduction}

The Mediterranean Sea is characterized by high biodiversity, habitat heterogeneity, and heavy anthropogenic pressure on the ecosystem (Coll et al., 2013; de la Hoz et al., 2018). It represents only $0.82 \%$ of the ocean surface and is considered a miniaturized ocean (Béthoux et al., 1999; Lejeusne et al., 2010), where nearly 17,000 marine species and $4-18 \%$ of global marine biodiversity are present (Coll et al., 2010). It is known to have a complex thermohaline, wind, and water flux-driven multi-scale circulation with interactive variabilities (Robinson et al., 2008; Jouini et al., 2016). The general water masses circulation in the Mediterranean has been described in detail (e.g.,

Guest editors: Angelo Bonanno, Othman Jarboui,

Salem Wniss Zgozi, Roberta Mifsud \& Luca Ceriola / Marine Ecosystems and Living Resources in the Central Mediterranean Sea

A. Bonanno $(\bowtie) \cdot$ G. Basilone

Istituto per l'Ambiente Marino Costiero - Consiglio

Nazionale delle Ricerche (IAMC-CNR), Capo Granitola,

Campobello Di Mazara, TP, Italy

e-mail: angelo.bonanno@iamc.cnr.it

S. W. Zgozi

Marine Biology Research Centre (MBRC), Tajura, Libya

O. Jarboui

Institut National des Sciences et Technologies de la Mer (INSTM), Sfax, Tunisia
Hopkins, 1985; Pinardi \& Masetti, 2000; Robinson et al., 2008), and is composed of three predominant and interacting spatial scales: basin scale (including the thermohaline circulation), sub-basin scale, and mesoscale (Robinson et al., 2008).

The Mediterranean Sea is traditionally divided into two large sub-regions (eastern and western subregions) and is characterized by east-west and northsouth gradients of physical and ecological factors (Coll et al., 2011; de la Hoz et al., 2018). The eastern region is more oligotrophic than the western one. The biological production is known to decrease from north to south and from west to east, thus being inversely related to the increase of temperature and salinity (Danovaro et al., 1999). The eastern and western subregions are connected through the Strait of Sicily in the Central Mediterranean, a transition area characterized by several small scale and mesoscale oceanographic phenomena (e.g., Robinson et al., 1999; Sorgente

\section{R. Mifsud}

Department of Fisheries and Aquaculture, Ministry for Sustainable Development, The Environment and Climate Change (DFA-MSDEC), Marsa, Malta

L. Ceriola $\cdot$ E. Arneri

FAO - MedSudMed Project. Food and Agriculture

Organization of the United Nations, Rome, Italy 
et al., 2011) and great abundance of marine living resources (e.g., Coll et al., 2010; Consoli et al., 2016).

A great effort for understanding the overall functioning of the whole Mediterranean Sea has been made in the past through specific multiannual international programs (e.g., the Mediterranean Targeted Project (MTP I) and the MTP II-MATER). In parallel, scientists from several institutions and countries carried out very important research programs to study the phenomenology of the Eastern Mediterranean (e.g., the POEM projects-POEM Group, 1992) and the Western Mediterranean (see EUROMODEL Group, 1995, for a general view).

In recent years, an increasing attention has been devoted also to the Central Mediterranean, and many of its characterizing features have been studied through specific experiments (e.g., Robinson et al., 1999; Sammari et al., 1999; Lermusiaux \& Robinson, 2001). Both the permanent and non-permanent character of the recognized physical features of the Central Mediterranean, as well as its degree of variability, have been studied (e.g., Olita et al., 2007; Gasparini et al., 2008; Drago et al., 2010; Placenti et al., 2013; Ben Ismail et al., 2014; Bonanno et al., 2014a; Jouini et al., 2016). Some studies singled out the influences of environmental variability on the biological resources in the Central Mediterranean (e.g., Levi et al., 2003; Garofalo et al., 2010; Rjeibi et al., 2010; Basilone et al., 2013, 2015, 2017; Bonanno et al., 2013, 2014b, 2015; Fiorentino et al., 2013; Khoufi et al., 2014; Barra et al., 2015; Jaziri et al., 2015; Lauria et al., 2016; Gargano et al., 2017). However, only part of the main features affecting the ecosystems and living resources in the Central Mediterranean has been fully understood. Moreover, considering that the Central Mediterranean is an important fishing area for the fishing fleets of several countries (Tunisia, Malta, Libya, Italy, and Egypt), the relationships between environmental variables and distribution and abundance of living resources have been pointed out as one of the key aspects to be explored by the Scientific Advisory Council (SAC) of the FAO General Fisheries Commission for the Mediterranean sea (FAO GFCM) (e.g., FAO, 2016). This aspect was considered particularly relevant especially in light of the observed environmental variability and the warming trend in the Mediterranean sea (Cheung et al., 2009; Sherman et al., 2009; Lejeusne et al., 2010; Philippart et al., 2011; Shaltout \& Omstedt, 2014; Lacoue-Labarthe et al., 2016).
Surveys at sea and direct observations are among the best sources of information for describing biological and environmental features, because sampling and collection are scientifically designed and standardized (Pennino et al., 2016). Most of the data and results presented in the present volume have been acquired during research surveys at sea and, in some cases, have been used to apply simulation models (e.g., GAM, GLM). Part of these surveys were planned and carried out in the framework of specific national and international research projects (e.g., the INSTM Fisheries Sciences research projects, the MAREFRAME project, etc.) or in the European Union Data Collection Framework (DCF-Reg. Ce. No. 199/2008, No. 665/2008 and Commission Decision $N^{\circ}$ 949/2008). This latter group of surveys belongs to routine annual surveys performed in many Mediterranean regions to provide fishery independent estimates of fish biomass for stock assessment groups delivering management advices. This is the case of MEDIAS (Mediterranean International Acoustic Survey; http://www.mediasproject.eu; MEDIAS, 2014) and MEDITS (Mediterranean International bottom trawl survey; http://www. sibm.it/SITO MEDITS; Bertrand et al., 2002). One of the most important fallouts of such fishery independent surveys is that they can contribute to provide the setting of the "Good Environmental Status" for an ecosystem, defining its reference state also by means of indicators yearly monitored (Borja et al., 2013).

\section{The FAO MEDSUDMED project}

The MedSudMed Project “Assessment and Monitoring of the Fishery Resources and the Ecosystems in the Strait of Sicily" is a regional Project executed by the Food and Agriculture Organization of the United Nations (FAO). MedSudMed is part of a network of FAO executed Projects supporting cooperation and fisheries management in the Mediterranean Sea (namely AdriaMed, CopeMed, EastMed, and MedSudMed). MedSudMed is funded since 2001 by the Italian Ministry of Agriculture, Food, and Forestry Policies (MiPAAF) and co-funded since 2012 by the Directorate-General for Maritime Affairs and Fisheries of the European Commission (DG MARE). The MedSudMed Project established and fuelled an international network of researchers from the Central Mediterranean countries: Libya, Malta, Tunisia, and 
Italy. The objective was to enhance scientific cooperation and gather new insights into fisheries and the marine ecosystem in the Central Mediterranean according to the Ecosystem Approach to Fisheries (EAF, FAO Fisheries Department, 2003). In this framework, data collection through cooperative research surveys at sea, retrieval and standardization of survey data gathered through time in Italy, Libya, Malta, and Tunisia have been supported. Standardized survey data were merged and a joint effort was put in place by experts of different countries to use them for drawing a wider picture on the main factors characterizing the biology and ecology of Central Mediterranean. Some achieved results have already been published as scientific papers (e.g., Bonanno et al., 2013, 2015; Placenti et al., 2013; Cuttitta et al., 2015) and/or technical documents (e.g., MedSudMed Technical Documents available at http://www. faomedsudmed.org/html/doc/Publications.asp). However, a wide amount of work is still needed to properly finalize the cooperative research activities carried out. In this context, the MedSudMed experts' network agreed to produce a series of scientific papers to be published in a single volume of a peer reviewed scientific journal.

\section{Volume outline}

The aim of the Hydrobiologia Special Issue "Marine ecosystems and living resources in Central Mediterranean sea" is to contribute to disseminate and make available to the scientific community new results from the cooperative research activities carried out by the scientific network established under FAO MedSudMed. The Special Issue includes a collection of fourteen papers embracing the following three main focus topics:

Life history traits of marine living resources

Life history traits for many fish species are still almost unknown in several areas of the Mediterranean Sea. Several documents on life histories of the most important small pelagic and demersal resources have been published (e.g., Ben Meriem, 1993, 1995; Ben Meriem et al., 1995; Levi et al., 2003; Basilone et al., 2004, 2006, 2013; Rjeibi et al., 2010; Garofalo et al., 2010; Bonanno et al., 2013, 2014b, 2015; Khoufi et al.,
2014, Jaziri et al., 2015; Lauria et al., 2016), pointing out, inter alia, a great variability depending on the habitat conditions. Information on biological parameters represents fundamental aspects for the proper understanding of population dynamics and for the application of the ecosystem approach to sustainable exploitation of marine resources. Further, many species are routinely monitored by Mediterranean countries throughout the southern-European and North-African waters. Data and results here presented provide useful information on distribution of exploited populations, thus making it possible future comparative studies on the ecology and dynamics of selected demersal and pelagic marine living resources.

Fanelli et al. (2018) analyzed the trophic ecology of European hake Merluccius merluccius by means of both stomach content and stable isotope analyses and correlated the results to environmental variables. According to both approaches, M. merluccius showed a clear ontogenetic shift in its diet in the Strait of Sicily. The results evidenced that trophic ecology of the species seems to be mostly influenced by mesoscale variability of water masses in this peculiar area of the Mediterranean Sea.

Examining otolith shapes of anchovy (Engraulis encrasicolus) caught off the open sea and the coastal area of the Gulf of Tunis, lagoon of Bizerte, and Lake of Ichkeul, Khemiri et al. (2018) found significant differences in otoliths shape between the open sea and inshore anchovy groups. Moreover, otolith shape of anchovy collected in the Lake of Ichkeul was distinct from the other groups. The obtained results highlighted the potential for using otolith shape analysis for anchovy stock identification, as well as the role of oceanographic features in determining stock separation.

Basilone et al. (2018), using otolith microstructure analysis and environmental variables obtained from satellite imagery, evidenced a clear effect of environmental conditions, particularly of sea surface temperature and chlorophyll-a concentration, on the growth histories of juveniles of E. encrasicolus.

Influence of oceanographic phenomena on the spatial distribution and abundance of marine resources

Environmental gradients (such as the salinity and temperature gradients), depending on their strength, 
act as barriers (leading to differences in fish assemblages) or determine smooth community gradients. Furthermore, environmental enrichment processes, as those occurring along the southern Sicilian coasts or along the southern Tunisian coasts, affect the food resources concentration, strongly influencing the density level of some species and determining their availability to the fisheries. Taking into account the broad range of environmental processes acting in the Central Mediterranean sea, the link between marine fish communities and environmental processes is discussed under different points of view. This information, under a holistic view, could provide a good basis for sustainable marine resources exploitation.

Based on the analysis of environmental factors and the acoustic data collected during two surveys carried out in the summer period in the Central Mediterranean sea, Ben Abdallah et al. (2018) found that most of the variability in small pelagic fish assemblages was due to the habitat differences between the northern (Strait of Sicily) and southern (Tunisian waters) parts of the Central Mediterranean. Specific spatially nested differences were identified, highlighting a kind of hierarchical structure in the pelagic habitat definitely allowing fish species to find their optimum in this highly variable ecosystem.

The analysis of spatio-temporal variability of fish community, coupled to the analysis of spatial indices, may provide a synthetic view of the fish community status evidencing, if any, the way a community changes. Adopting this approach, Bonanno et al. (2018) analyzed changes in the pelagic fish community structure in an upwelling ecosystem of the central Mediterranean Sea in a 10 years period. The results evidenced a quite stable community structure, characterized by spatial occupation strongly driven by ecosystem characteristics and modulated according to specie-specific behavior.

Zgozi et al. (2018) carried out a habitat suitability study for a key small pelagic fish species (Sardinella aurita) in the central Mediterranean sea. The application of generalized additive models (GAM) to survey data singled out the key role of depth and temperature in driving higher $S$. aurita aggregations in the Libyan, Maltese, and southern Sicily waters.

Predictive modeling of the European hake (Merluccius merluccius) distribution was developed by Garofalo et al. (2018) in the south-central Mediterranean Sea by means of historical fisheries- independent databases available in the region. Prediction maps allowed to improve the knowledge on the distributional patterns of one of the most important shared stocks in the south-central Mediterranean. This is essential for the implementation of spatial-based fisheries management.

Greater knowledge on the spatial distribution and habitat requirements of two horse mackerels (Trachurus trachurus and Trachurus mediterraneus) in the south-central Mediterranean was obtained by Milisenda et al. (2018), by applying species distribution models. Predictive distribution maps revealed a clear spatial segregation between biomass HotSpots (areas with the highest abundances) of the two species, which depends on complex abiotic and biotic relationships.

Phytoplankton and zooplankton in the physical environment

A knowledge gap still exists on the environmental factors affecting phytoplankton and zooplankton communities. In particular, work is still needed to develop exhaustive models describing the processes driving the energy exchange along the trophic food web levels from the primary producers up to top consumers (Rumolo et al., 2016). Although its relevance, only few studies have already addressed this subject in the Central Mediterranean (e.g., Bonomo et al., 2012; Valenti et al., 2012, 2017; Denaro et al., 2013a, b). In the present volume, some attributes of the physical-chemical environment that are relevant to phytoplankton and zooplankton research have been studied for the Central Mediterranean.

Bonomo et al. (2018), working on data and samples collected in summer 2010, from coastal and offshore areas off the eastern-Libyan coast, found that the distribution of coccolithophore taxa is influenced by environmental parameters: K-strategist taxa were related to nutrient-depleted surface/intermediate waters, whereas lower photic zone taxa were influenced by the development of the deep chlorophyll maximum and high salinity values, well below the thermocline. The obtained results confirm that a vertical species zonation characterizes the easternLibyan coast, where the holococcolithophores represent one of the most important features of coccolithophore production during summer.

Taking advantage of the quasi-simultaneous collection of a large ichthyoplanktonic dataset in different 
regions of the Central Mediterranean Sea (Italian/ Maltese, Tunisian, and Libyan waters), Cuttitta et al. (2018) identified the main environmental drivers that control the structure of the larval fish assemblages in this area. Random Forest classification model highlighted the essential role of the bathymetry, while Lagrangian simulations evidenced the action of the hydrodynamics in mixing neritic and oceanic assemblages in the Italian/Maltese and partially in Libyan waters.

The combined use of field data on anchovy ( $E$. encrasicolus) egg distribution in the Central Mediterranean Sea on both sides of the Strait of Sicily (Sicilian-Maltese and Tunisian waters) and Lagrangian simulations were used by Patti et al. (2018) to assess the pattern of connectivity between these two sub-areas as a result of spawning activity. The simulation runs showed considerable (up to 20\%) rates of particle exchange in both directions (from Tunisian to Sicilian-Maltese waters and vice versa). However, the actual larval exchange rates across the Sicily Strait are supposed to be significantly lower (about $1 \%$ ), due to the typical high mortality rates of anchovy early stages. Such findings contribute to support the hypothesis that the anchovy population sub-units in the Strait of Sicily can be considered as separate fish stocks for the evaluation of their optimum exploitation rates.

Zarrad et al. (2018), analyzing samples and data collected in the Gulf of Gabès (south Tunisia), singled out that this is an important area for anchovy $(E$. encrasicolus) and round sardinella ( $S$. aurita) spawning. The developmental stages of both species showed low spatial overlap, indicating that the spawning habitats of these species are spatially differentiated with round sardinella mainly spawning in the center of the Gulf and anchovy spawning areas located in the inner parts of the Gulf and in offshore waters.

Differences in abundance, biomass, and assemblage structure of zooplankton and anchovy ( $E$. encrasicolus) population were observed by Rumolo et al. (2018). Such differences affected the isotopic composition of anchovy, which showed changes in $\delta^{15} \mathrm{~N}$ and $\delta^{13} \mathrm{C}$. The obtained results evidenced that $E$. encrasicolus may be affected by any environmental change that influences the plankton community, which is the basis of the diet of these fishes. Such findings highlighted the importance to further investigate the trophic relationships among different compartments of the food web, as well as the possible environmental influences, in order to obtain a more complete picture of ecosystem functioning.

The overall importance of the Strait of Sicily as a boundary area between the western- and easternMediterranean sub-regions and as an important biodiversity hotspot was highlighted in a review by $\mathrm{Di}$ Lorenzo et al. (2018). The authors, taking into account the increasing threats by expanding anthropogenic pressures in the area, highlighted the necessity to adopt specific conservation measures at national and international level in order to protect the relevant and vulnerable habitats in the Strait of Sicily.

\section{Future perspectives}

Environmental changes affect, in different ways, all the organisms inhabiting the Central Mediterranean, leading to changes in species distribution and abundance, influencing trophic food webs and determining structural and functional modification at ecosystem level (e.g., Shaltout \& Omstedt, 2014; LacoueLabarthe et al., 2016). From the physical point of view, in agreement with Robinson et al. (2008), the complete story has not yet been told. Current understanding of the environment (as inferred by monitoring programs) is still limited, due to the complex physical and biological interactions acting at multiple spatial and temporal scales, and more effort and time are needed to reveal the story and see how many states of the circulation exist, what changes occur and whether or not conditions repeat.

In this Special Issue, new bricks toward a better understanding of the several factors characterizing the marine ecosystem in this area of the Central Mediterranean have been provided. However, studies are still necessary to see the story unfold and to understand several factors like, for example, the effects of climate change or sea water acidification on the marine ecosystem. Some environmental changes occurring in the Mediterranean Sea have been recently singled out by Borghini et al. (2014) and by Schroeder et al. (2017). The results of such papers highlighted the importance of a continuous monitoring of oceanographic conditions in the Central Mediterranean, mainly due to the position of this peculiar area.

Climate change, through long-term temperature increase and a higher frequency of short-term extreme 
events, is undoubtedly affecting the biology and ecology of the organisms in several oceanic regions (e.g., Coll et al., 2010). Most visible changes regard species life cycle, reproductive effort and demography; other changes concern indirect adaptive responses such as physiological adjustments and microevolutionary processes (Lejeusne et al., 2010). A direct consequence of sea water warming is a simultaneous increase in the abundance of thermophilic and thermo-tolerant species and the disappearance or rarefaction of 'cold' steno-thermal species as already observed in recent years in the Mediterranean Sea (UNEP-MAP-RAC/SPA, 2008). Historically, the Eastern Mediterranean has been colonized by Lessepsian migrants, non-indigenous species (NIS) entering through the Suez Canal, whereas the Western Mediterranean hosted NIS entered through the Gibraltar Strait. Another source of NIS in the Mediterranean has been the spread through mariculture and shipping (Katsanevakis et al., 2013). Current numbers on NIS are high. A recent checklist identified 986 alien species in the Mediterranean: 775 in the eastern Mediterranean, 249 in the central Mediterranean, 190 in the Adriatic Sea, and 308 in the Western Mediterranean (Zenetos et al., 2012). Along the coast of Middle-East and North Africa until the Strait of Sicily, some NIS recently gained importance in local fisheries (Streftaris \& Zenetos, 2006; Ounifi-Ben Amor et al., 2015). New dynamics are further expected due to the doubling of the Suez Channel in 2015. The Strait of Sicily has been regarded as a biogeographic barrier to a sudden expansion of NIS In the western Mediterranean (Quignard \& Tomasini, 2000). However, this role could be modified as response of climate change or to unexpected variations of the main oceanographic phenomena. Accordingly, continuous monitoring of the change in biodiversity is to be considered a priority in next future.

Ocean acidification may lead, in some cases, to changes in the relative species composition at a given trophic level, potentially affecting its productivity (Le Quesne \& Pinnegar, 2011). Possible effects at the organism level include reduced growth and reproductive output, increased predation and mortality, alteration in feeding rates and behavior, and reduced thermal tolerance. Whilst general theories for understanding the sensitivity of species to acidification are being developed (Melzner et al., 2009), closely related taxa have shown different responses in the face of acidification (Miller et al., 2009). Laboratory experiments could be necessary to understand the potential effects of sea water acidification on fish species. Once direct biological responses of organisms have been established, these need to be scaled up to populationlevel for developing hypotheses on potential impacts on fisheries production and yields. Furthermore, habitat availability and prey or predator abundance may also be correlated with acidification effects; therefore, accurately model-based predicting responses in population dynamics require explicit inclusion and understanding of community-level processes. As for climate change, monitoring the implications of sea water acidification in Central Mediterranean should be considered a priority for the coming years.

At Mediterranean level, there is increased awareness that global changes are underway, and will probably have ecological, social and economic impacts (see the Malta Declaration, 2017). To cope with potential changes, further knowledge on global phenomena like climate changes and sea water acidification, through continue cooperative studies, will be necessary. In addition, the proper dissemination of achieved results on dedicated publications will be an asset to ensure that knowledge becomes the ground for proper management and mitigation and/or adaptive strategy development.

In this complex and constantly evolving context, regional initiatives like the FAO MedSudMed Project could play an important role by providing a stable and coordinated environment for the scientific cooperation. The resulting research activities may contribute to better understanding the complex marine ecosystem in the Central Mediterranean and permit to interpret many responses of the marine resources to environmental forcings.

All authors sincerely hope this set of papers will generate new ideas, new concepts, and baselines for new research lines.

Acknowledgements The authors thank all Hydrobiologia editors and their collaborators for producing the present collection of papers, all editors that assisted in the review process, all referees that have written essential and extensive reviews of these manuscripts, as well as the staff of Springer for producing the final complete volume on time. The preparation of this special issue was supported by the FAO Project MedSudMed 'Assessment and Monitoring of the Fishery Resources and the Ecosystems in the Straits of Sicily', which is funded by the Italian Ministry for Agriculture Food and 
Forestry Policies (MiPAAF) and co-funded by the DirectorateGeneral for Maritime Affairs and Fisheries of the European Commission (DG MARE).

\section{References}

Basilone, G., C. Guisande, B. Patti, S. Mazzola, A. Cuttitta, A. Bonanno \& A. Kallianiotis, 2004. Linking habitat conditions and growth in the European anchovy (Engraulis encrasicolus). Fisheries Research 68: 9-19.

Basilone, G., C. Guisande, B. Patti, S. Mazzola, A. Cuttitta, A. Bonanno, A. R. Vergara \& I. Maneiro, 2006. Effect of habitat conditions on reproduction of the European anchovy (Engraulis encrasicolus) in the Strait of Sicily. Fisheries Oceanography 15(4): 271-280.

Basilone, G., A. Bonanno, B. Patti, S. Mazzola, M. Barra, A. Cuttitta \& R. Mcbride, 2013. Spawning site selection by European anchovy (Engraulis encrasicolus) in relation to oceanographic conditions in the Strait of Sicily. Fisheries Oceanography 22(4): 309-323.

Basilone, G., K. Ganias, R. Ferreri, M. D’Elia, E.M. Quinci, S. Mazzola, A. Bonanno, 2015. Application of GAMs and multinomial models to assess the spawning pattern of fishes with daily spawning synchronicity: A case study in the European anchovy (Engraulis encrasicolus) in the central Mediterranean Sea. Fisheries Research 167: 92-100.

Basilone, G., S. Mangano, M. Pulizzi, I. Fontana, G. Giacalone, R. Ferreri, A. Gargano, S. Aronica, M. Barra, S. Genovese, P. Rumolo, S. Mazzola \& A. Bonanno, 2017. European anchovy (Engraulis encrasicolus) age structure and growth rate in two contrasted areas of the Mediterranean Sea: the paradox of faster growth in oligotrophic seas. Mediterranean Marine Science 18(3): 504-516.

Basilone, G., R. Ferreri, S. Mangano, M. Pulizzi, A. Gargano, M. Barra, S. Mazzola, I. Fontana, G. Giacalone, S. Genovese, S. Aronica \& A. Bonanno, 2018. Effects of habitat conditions at hatching time on growth history of offspring European anchovy, Engraulis encrasicolus, in the Central Mediterranean Sea. Hydrobiologia. https://doi.org/10. 1007/s10750-018-3625-9 (this issue).

Barra, M., P. Petitgas, A. Bonanno, S. Somarakis, M. Woillez, A. Machias, S. Mazzola, G. Basilone \& M. Giannoulaki, 2015. Interannual Changes in biomass affect the spatial aggregations of anchovy and sardine as evidenced by geostatistical and spatial indicators. PLoS ONE 10(8): e0135808.

Ben Abdallah, L., M. Barra, A. Gaamour, S. Khemiri, S. Genovese, R. Mifsud, G. Basilone, I. Fontana, G. Giacalone, S. Aronica, S. Mazzola, O. Jaboui \& A. Bonanno, 2018. Small pelagic fish assemblages in relation to environmental regimes in the Central Mediterranean. Hydrobiologia. https://doi.org/10.1007/s10750-018-3540-0 (this issue).

Ben Ismail, S., K. Schroeder, C. Sammari, G. P. Gasparini, M. Borghini \& L. Aleya, 2014. Interannual variability of water mass properties in the Tunisia-Sicily Channel. Journal of Marine Systems 135: 14-28.
Ben Meriem, S., 1993. Taille de première maturité sexuelle et période de ponte de Penaeus kerathurus du golfe de Gabès (Decapoda, Penaeoidea). Crustaceana 65(1): 82-96.

Ben Meriem, S., 1995. Caractères biométriques de Penaeus kerathurus du golfe de Gabès (Decapoda, Penaeoidea). Crustaceana 68(5): 583-596.

Ben Mariem, S., H. Gharbi \& S. Ezzedine-Nadaj, 1995. Mortalitè par pêche et rendement par recrue du rouget de vase (Mullus barbatus, Linneus, 1758) de Tunisie. Mar. Life 5(2): 35-46.

Bertrand, J. A., L. Gil De Sola, C. Papaconstantinou, G. Relini \& A. Souplet, 2002. The general specifications of the MEDITS surveys. Scientia Marina 66(2): 9-17.

Béthoux, J. P., B. Gentili, P. Morin, E. Nicolas, C. Pierre \& D. Ruiz-Pino, 1999. The Mediterranean Sea: a miniature ocean for climatic and environmental studies and a key for the climatic functioning of the North Atlantic. Progress in Oceanography 44: 131-146.

Bonanno, A., S. Zgozi, A. Cuttitta, A. El Turki, A. Di Nieri, H. Ghmati, G. Basilone, S. Aronica, M. Hamza, M. Barra, S. Genovese, F. Falco, L. Knittweis, R. Mifsud, B. Patti, T. Bahri, G. Giacalone, I. Fontana, G. Tranchida \& S. Mazzola, 2013. Influence of environmental variability on anchovy early life stages (Engraulis encrasicolus) in two different areas of the Central Mediterranean Sea. Hydrobiologia 701: 273-287.

Bonanno, A., F. Placenti, G. Basilone, R. Mifsud, S. Genovese, B. Patti, M. Di Bitetto, S. Aronica, M. Barra, G. Giacalone, R. Ferreri, I. Fontana, G. Buscaino, G. Tranchida, E. Quinci \& S. Mazzola, 2014a. Variability of water mass properties in the Strait of Sicily in summer period of 1998-2013. Ocean Science 10: 1-12.

Bonanno, A., M. Giannoulaki, M. Barra, G. Basilone, A. Machias, S. Genovese, S. Goncharov, S. Popov, P. Rumolo, M. Di Bitetto, S. Aronica, B. Patti, I. Fontana, G. Giacalone, R. Ferreri, G. Buscaino, S. Somarakis, M. Pirounaki, S. Tsoukali \& S. Mazzola, 2014b. Habitat selection response of small pelagic fish in different environments. Two examples from the oligotrophic Mediterranean Sea. PLoS ONE 9(7): e101498.

Bonanno, A., S. Zgozi, G. Basilone, M. Hamza, M. Barra, S. Genovese, P. Rumolo, A. Nfate, M. Elsger, S. Goncharov, S. Popov, R. Mifsud, T. Bahri, G. Giacalone, I. Fontana, B. Buongiorno Nardelli, S. Aronica, L. Ceriola, B. Patti, R. Ferreri, S. Colella, G. Volpe \& S. Mazzola, 2015. Acoustically detected pelagic fish community in relation to environmental conditions observed in the Central Mediterranean sea: a comparison of Libyan and SicilianMaltese coastal areas. Hydrobiologia 755: 209-224.

Bonanno, A., M. Barra, R. Mifsud, G. Basilone, S. Genovese, M. Di Bitetto, S. Aronica, G. Giacalone, I. Fontana, S. Mangano, R. Ferreri, M. Pulizzi, P. Rumolo, A. Gargano, G. Buscaino, P. Calandrino, A. Di Maria \& S. Mazzola, 2018. Space utilization by key species of the pelagic fish community in an upwelling ecosystem of the Mediterranean Sea. Hydrobiologia. https://doi.org/10.1007/s10750-0173350-9 (this issue).

Bonomo, S., M. Grelaud, A. Incarbona, E. Malinverno, F. Placenti, A. Bonanno, E. D. Stefano, B. Patti, M. Sprovieri, S. Genovese, P. Rumolo, S. Mazzola, S. Zgozi \& P. Ziveri, 2012. Living coccolithophores from the Gulf of Sirte 
(southern Mediterranean Sea) during the summer of 2008. Micropaleontology 58: 487-503.

Bonomo, S., F. Placenti, S. Zgozi, M. Torri, E. M. Quinci, A. Cuttitta, S. Genovese, S. Mazzola, S. Aronica, M. Barra, A. El Turki, M. Hamza, O. Uheshi, M. Bara, M. Assughayer \& A. Bonanno, 2018. Relationship between coccolithophores and the physical and chemical oceanography of eastern Libyan coastal waters. Hydrobiologia. https://doi.org/10. 1007/s10750-017-3227-y (this issue).

Borghini, M., H. Bryden, K. Schroeder, S. Sparnocchia \& A. Vetrano, 2014. The Mediterranean is becoming saltier. Ocean Science 10(4): 693-700.

Borja, A., M. Elliott, J. H. Andersen, A. C. Cardoso, J. Carstensen, J. G. Ferreira, A. Heiskanen, J. C. Marques, J. M. Neto, H. Teixeira, L. Uusitalo, M. C. Uyarra \& N. Zampoukas, 2013. Good Environmental Status of marine ecosystems: what is it and how do we know when we have attained it? Marine Pollution Bulletin 76: 16-27.

Cheung, W. W. L., V. W. Y. Lam, J. L. Sarmiento, K. Kearney, R. Watson \& D. Pauly, 2009. Projecting global marine biodiversity impacts under climate change scenarios. Fish and Fisheries 10: 235-251.

Coll, M., C. Piroddi, J. Steenbeek, K. Kaschner, F. Ben Rais Lasram, J. Aguzzi, E. Ballesteros, C. N. Bianchi, C. Corbera, T. Dailianis \& R. Danovaro, 2010. The biodiversity of the Mediterranean Sea: estimates, patterns, and threats. PLoS ONE 5: e11842.

Coll, M., C. Piroddi, C. Albouy, F. Ben Rais Lasram, W. W. L. Cheung, V. Christensen, V. S. Karpouzi, F. Guilhaumon, D. Mouillot, M. Paleczny, M. L. Palomares, J. Steenbeek, P. Trujillo, R. Watson \& D. Pauly, 2011. The Mediterranean Sea under siege: spatial overlap between marine biodiversity, cumulative threats and marine reserves. Global Ecology and Biogeography 21: 465-480.

Coll, M., P. Cury, E. Azzurro, M. Bariche, G. Bayadas, J. M. Bellido, C. Chaboud, J. Claudet, A. El-Sayed, D. Gascuel, L. Knittweis, C. Pipitone, Y. Samuel-Rhoads, S. Taleb, S. Tudela \& A. Valls, 2013. The scientific strategy needed to promote a regional ecosystem-based approach to fisheries in the Mediterranean and Black Seas. Reviews in Fish Biology and Fisheries 23: 415-434.

Consoli, P., V. Esposito, P. Battaglia, C. Altobelli, P. Perzia, T. Romeo, S. Canese \& F. Andaloro, 2016. Fish distribution and habitat complexity on banks of the Strait of Sicily (Central Mediterranean Sea) from remotely-operated vehicle (ROV) explorations. PLoS ONE 11: e0167809.

Cuttitta, A., B. Patti, T. Maggio, E. M. Quinci, A. M. Pappalardo, V. Ferrito, V. De Pinto, M. Torri, F. Falco, A. Nicosia, M. Musco, G. M. Armeri, F. Placenti, G. Tranchida, R. Mifsud, A. Bonanno \& S. Mazzola, 2015. Larval population structure of Engraulis encrasicolus in the Strait of Sicily as revealed by morphometric and genetic analysis. Fisheries Oceanography 24: 135-149.

Cuttitta, A., M. Torri, R. Zarrad, S. Zgozi, O. Jarboui, E. M. Quinci, M. Hamza, E. Abdulfatah, D. Haddoud, A. El Turki, A. Ramadan, H. Missaoui, R. Mifsud, S. Bonomo, S. Mazzola \& B. Patti, 2018. Linking surface hydrodynamics to planktonic ecosystem: the case study of the ichthyoplanktonic assemblages in the Central Mediterranean Sea. Hydrobiologia. https://doi.org/10.1007/s10750-017-3483$\mathrm{x}$ (this issue). de la Hoz, C. F., E. Ramos, A. Puente, F. Méndez, M. Menéndez, J. A. Juanes \& I. J. Losada, 2018. Ecological typologies of large areas. An application in the Mediterranean Sea. Journal of Environmental Management 205: 59-72.

Danovaro, R., A. Dinet, G. Duineveld \& A. Tselepides, 1999. Benthic response to particulate fluxes in different trophic environments: a comparison between the Gulf of LionsCatalan Sea (western-Mediterranean) and the Cretan Sea (eastern-Mediterranean). Progress in Oceanography 44: 287-312.

Denaro, G., D. Valenti, B. Spagnolo, A. Bonanno, G. Basilone, S. Mazzola, S. W. Zgozi \& S. Aronica, 2013a. Stochastic dynamics of two picophytoplankton populations in a real marine ecosystem. Acta Phys Polonica B 44(5): 977.

Denaro, G., D. Valenti, B. Spagnolo, G. Basilone, S. Mazzola, S. W. Zgozi, S. Aronica \& A. Bonanno, 2013b. Dynamics of two picophytoplankton groups in Mediterranean Sea: analysis of the deep chlorophyll maximum by a stochastic advection-reaction-diffusion model. PLoS ONE 8(6): e66765.

Di Lorenzo, M., M. Sinerchia \& F. Colloca, 2018. The North sector of the Strait of Sicily: a priority area for conservation in the Mediterranean Sea. Hydrobiologia. https://doi.org/ 10.1007/s10750-017-3389-7 (this issue).

Drago, A., R. Sorgente \& A. Olita, 2010. Sea temperature, salinity and total velocity climatological fields for the south-central Mediterranean Sea. GCP/RER/010/ITA/ MSM-TD14. MedSudMed Technical Documents, 14: $35 \mathrm{pp}$.

EUROMODEL Group, 1995. Progress from 1989 to 1992 in understanding the circulation of the Western Mediterranean Sea. Oceanologica Acta 18: 255-271.

Fanelli, E., P. Rumolo, M. Barra, G. Basilone, S. Genovese \& A. Bonanno, 2018. Mesoscale variability in the trophic ecology of the European hake Merluccius merluccius in the Strait of Sicily. Hydrobiologia. https://doi.org/10.1007/ s10750-017-3268-2 (this issue).

FAO Fisheries Department, 2003. The ecosystem approach to fisheries. FAO Technical Guidelines for Responsible Fisheries. No. 4, Suppl. 2. Rome, Italy, 112 pp.

FAO, 2016. General Fisheries Commission for the Mediterranean. Report of the eighteenth session of the Scientific Advisory Committee on Fisheries. Nicosia, Cyprus, 21-23 March 2016. FAO Fisheries and Aquaculture Report No. R1154. Rome, Italy, 254 pp.

Fiorentino, F., O. Ben Hadj Hamida, S. Ben Meriem, A. Gaamour, M. Gristina, O. Jarboui, L. Knittweis, O. Rjeibi \& L. Ceriola, 2013. Synthesis of information on some demersal crustaceans relevant for fisheries target species in the south-central Mediterranean Sea. GCP/RER/010/ITA/ MSM-TD-32. MedSudMed Technical Documents, 32. $120 \mathrm{pp}$.

Gargano, F., G. Garofalo \& F. Fiorentino, 2017. Exploring connectivity between spawning and nursery areas of $\mathrm{Mul}$ lus barbatus (L., 1758) in the Mediterranean through a dispersal model. Fisheries Oceanography 26(4): 476-497.

Garofalo, G., L. Ceriola, M. Gristina, F. Fiorentino \& R. Pace, 2010. Nurseries, spawning grounds and recruitment of Octopus vulgaris (Cuvier, 1797) in the Strait of Sicily (central Mediterranean). ICES Journal of Marine Science 67(7): 1363-1371. 
Garofalo, G., S. Fezzani, F. Gargano, G. Milisenda, O. Ben Abdallah, N. Ben Hadj Hamida, O. Jarboui, B. ChemmamAbdelkader, W. Khoufi, R. Micallef, R. Mifsud, S. Gancitano, P. Rizzo, S. Zgozi, L. Ceriola, E. Arneri \& F. Fiorentino, 2018. Predictive distribution models of European hake in the south-central Mediterranean Sea. Hydrobiologia. https://doi.org/10.1007/s10750-017-33385 (this issue).

Gasparini, G. P., A. Bonanno, S. Zgozi, G. Basilone, M. Borghini, G. Buscaino, A. Cuttitta, N. Essarbout, S. Mazzola, B. Patti, A. B. Ramadan, K. Schroeder, T. Bahri \& F. Massa, 2008. Evidence of a dense water vein along the Libyan continental margin. Annales Geophysicae 26: 1-6.

Hopkins, T. S., 1985. Physics of the sea. In Margalef, R. (ed.), Key Environments: Western Mediterranean. Pergamon, Oxford: 100-125.

Jaziri, H., R. Ferreri, W. Khoufi, S. El Fehri, S. Ben Meriem, M. Pulizzi, S. Mangano, A. Bonanno, S. Mazzola \& G. Basilone, 2015. Seasonal variation of reproductive traits of the caramote prawn in the Gulf of Tunis. Aquatic Living Resources 28: 89-98.

Jouini, M., K. Beranger, T. Arsouze, J. Beuvier, S. Thiria, M. Crepon \& I. Taupier-Letage, 2016. The Sicily Channel surface circulation revisited using a neural clustering analysis of a high-resolution simulation. Journal of Geophysical Research: Oceans 121: 4545-4567.

Katsanevakis, S., A. Zenetos, C. Belchior \& A. C. Cardoso, 2013. Invading European Seas: assessing pathways of introduction of marine aliens. Ocean and Coastal Management 76: 64-74.

Khemiri, S., A. Gaamour, L. Ben Abdallah \& S. Fezzani, 2018. The use of otolith shape to determine stock structure of Engraulis encrasicolus along the Tunisian coast. Hydrobiologia. https://doi.org/10.1007/s10750-017-3305-1 (this issue).

Khoufi, W., R. Ferreri, H. Jaziri, S. El Fehri, A. Gargano, S. Mangano, S. Ben Meriem, M. S. Romdhane, A. Bonanno \& G. Basilone, 2014. Reproductive potential aspects in hake (Merluccius merluccius) in the central Mediterranean Sea: first observations from Tunisian waters. Journal of Marine Biology Association of the United Kingdom 94: 1545-1556.

Lacoue-Labarthe, T., P. A. L. D. Nunes, P. Ziveri, M. Cinar, F. Gazeau, J. M. Hall-Spencer, N. Hilmi, P. Moschella, A. Safa, D. Sauzade \& C. Turley, 2016. Impacts of ocean acidification in a warming Mediterranean Sea: an overview. Regional Studies in Marine Science 5: 1-11.

Lauria, V., G. Garofalo, M. Gristina \& F. Fiorentino, 2016. Contrasting habitat selection amongst cephalopods in the Mediterranean Sea: when the environment makes the difference. Marine Environmental Research 119: 252-266.

Le Quesne, W. J. F. \& J. K. Pinnegar, 2011. The potential impacts of ocean acidification: scaling from physiology to fisheries. Fish and Fisheries 13(3): 333-344.

Lejeusne, C., P. Chevaldonné, C. Pergent-Martini, C. F. Boudouresque \& T. Pérez, 2010. Climate change effects on a miniature ocean: the highly diverse, highly impacted Mediterranean Sea. Trends in Ecology \& Evolution 25: 250-260.

Lermusiaux, P. F. J. \& A. R. Robinson, 2001. Features of dominant mesoscale variability, circulation patterns and dynamics in the Strait of Sicily. Deep-Sea Research Part I 48: 1953-1997.

Levi, D., M. G. Andreoli, A. Bonanno, F. Fiorentino, G. Garofalo, S. Mazzola, G. Norrito, B. Patti, G. Pernice, S. Ragonese, G. B. Giusto \& P. Rizzo, 2003. Embedding sea surface temperature anomalies into the stock recruitment relationship of red mullet (Mullus barbatus L. 1758) in the Strait of Sicily. Scientia 67(1): 259-268.

Malta Declaration, 2017. Malta MedFish4Ever Ministerial Declaration. Ministerial conference on the sustainability of Mediterranean fisheries. 30 March 2017 (available on internet at https://ec.europa.eu/fisheries/sites/fisheries/ files/2017-03-30-declaration-malta.pdf).

MEDIAS Handbook, 2014. Handbook of Mediterranean international acoustic surveys (available on internet at http:// www.mediasproject.eu/medias/website/handbooks-menu. html).

Melzner, F., M. A. Gutowska, M. Langenbuch, S. Dupont, M. Lucassen, M. C. Thorndyke, M. Bleich \& H. O. Portner, 2009. Physiological basis for high $\mathrm{CO}_{2}$ tolerance in marine ectothermic animals: pre-adaptation through lifestyle and ontogeny? Biogeosciences 6: 2313-2331.

Milisenda, G., G. Garofalo, S. Fezzani, O. Rjeibi, O. Jarboui, B. Chemmam, L. Ceriola, A. Bonanno, S. Genovese, G. Basilone, R. Mifsud, V. Lauria, M. Gristina, F. Colloca \& F. Fiorentino, 2018. Biomass HotSpot distribution model and spatial interaction of two exploited species of horse mackerel in the south-central Mediterranean Sea. Hydrobiologia. https://doi.org/10.1007/s10750-017-3336-7 (this issue).

Miller, A. W., A. C. Reynolds, C. Sobrino \& G. F. Riedel, 2009. Shellfish face uncertain future in high $\mathrm{CO}_{2}$ world: influence of acidification on oyster larvae calcification and growth in estuaries. PLoS ONE 4(5): e5661.

Olita, A., R. Sorgente, S. Natale, S. Gabersek, A. Ribotti, A. Bonanno \& B. Patti, 2007. Effects of the 2003 European heatwave on the Central Mediterranean Sea: surface fluxes and the dynamical response. Ocean Science 3: 273-289.

Ounifi-Ben Amor, K., M. Rifi, R. Ghanem, I. Draeif, J. Zaouali \& J. Ben Souissi, 2015. Update of alien fauna and new records from Tunisian marine waters. Mediterranean Marine Science 17(1): 124-143.

Patti, B., R. Zarrad, O. Jarboui, A. Cuttitta, G. Basilone, S. Aronica, F. Placenti, G. Tranchida, G. M. Armeri, G. Buffa, R. Ferreri, S. Genovese, M. Musco, A. Traina, M. Torri, R. Mifsud \& S. Mazzola, 2018. Anchovy (Engraulis encrasicolus) early life stages in the Central Mediterranean Sea: connectivity issues emerging among adjacent subareas across the Strait of Sicily. Hydrobiologia. https://doi. org/10.1007/s10750-017-3253-9 (this issue).

Pennino, M. G., D. Conesa, A. López-Quílez, F. Munõz, A. Fernández \& J. M. Bellido, 2016. Fishery-dependent and independent data lead to consistent estimations of essential habitats. ICES Journal of Marine Science 73(9): 2302-2310.

Philippart, C. J. M., R. Anadón, R. Danovaro, J. W. Dippner, K. F. Drinkwater, S. J. Hawkins, T. Oguz, G. O'Sullivan \& P. C. Reid, 2011. Impacts of climate change on European marine ecosystems: observations, expectations and indicators. Journal of Experimental Marine Biology and Ecology 400: 52-69. 
Pinardi, N. \& E. Masetti, 2000. Variability of the large scale general circulation of the Mediterranean Sea from observations and modelling: a review. Palaeogeography Palaeoclimatology Palaeoecology 158: 153-173.

Placenti, F., K. Schroeder, A. Bonanno, S. Zgozi, M. Sprovieri, M. Borghini, P. Rumolo, G. Cerrati, S. Bonomo, S. Genovese, G. Basilone, D. A. Haddoud, B. Patti, A. El Turki, M. Hamza \& S. Mazzola, 2013. Water masses and nutrient distribution in the Gulf of Syrte and between Sicily and Libya. Journal of Marine Systems 121-122: 36-46.

POEM Group, 1992. General circulation of the eastern Mediterranean. Earth Sciences Review 32: 285-308.

Quignard, J. P. \& J. A. Tomasini, 2000. Mediterranean fish biodiversity. Biologia Marina Mediterranea 7(3): 1-66.

Rjeibi, O., A. Gaamour \& H. Missaoui, 2010. Kinetics of ooegenesis and spawning strategy of the red spiny lobster Palinurus elephas. Journal of Crustacean Biology 30: 401-412.

Robinson, A. R., J. Sellschopp, A. Warn-Varnas, W. G. Leslie, C. J. Lozano, P. J. Haley, L. A. Anderson \& P. F. J. Lermusiaux, 1999. The Atlantic ionian stream. Jornal of Marine System 20: 129-156.

Robinson, A. R., W. G. Leslie, A. Theocharis \& A. Lascaratos, 2008. Mediterranean Sea circulation. In Steele, J. H. (ed.), Encyclopedia of Ocean Sciences, 2nd ed. Academic Press, Oxford: 710-725.

Rumolo, P., A. Bonanno, M. Barra, E. Fanelli, M. Calabrò, S. Genovese, R. Ferreri, S. Mazzola \& G. Basilone, 2016. Spatial variations in feeding habits and trophic levels of two small pelagic fish species in the central Mediterranean Sea. Marine Environmental Research 115: 65-77.

Rumolo, P., E. Fanelli, M. Barra, G. Basilone, S. Genovese, S. Gherardi, R. Ferreri, A. Gargano, S. Mazzola \& A. Bonanno, 2018. Trophic relationships between anchovy (Engraulis encrasicolus) and zooplankton in the Strait of Sicily (Central Mediterranean sea): a stable isotope approach. Hydrobiologia. https://doi.org/10.1007/s10750017-3334-9 (this issue).

Sammari, C., C. Millot, I. Taupier-Letage, A. Stefani \& M. Brahim, 1999. Hydrological characteristics in the Tunisian-Sardinia-Sicily area during spring 1995. Deep-Sea Research I 46: 1671-1703.

Schroeder, K., J. Chiggiato, S. A. Josey, M. Borghini, S. Aracri \& S. Sparnocchia, 2017. Rapid response to climate change in a marginal sea. Scientific Reports 7: 4065.

Shaltout, M. \& A. Omstedt, 2014. Recent sea surface temperature trends and future scenarios for the Mediterranean Sea. Oceanologia 56(3): 411-443.
Sherman, K., I. M. Belkin, K. D. Friedland, J. O'Reilly \& K. Hyde, 2009. Accelerated warming and emergent trends in fisheries biomass yields of the world's large marine ecosystems. AMBIO: A Journal of the Human Environment 38(4): 215-224.

Sorgente, R., A. Olita, P. Oddo, L. Fazioli \& A. Ribotti, 2011. Numerical simulation and decomposition of kinetic energy in the Central Mediterranean: insight on mesoscale circulation and energy conversion. Ocean Science 7: 503-519.

Streftaris, N. \& A. Zenetos, 2006. Alien marine species in the Mediterranean - the 100 'worst invasives' and their impact. Mediterranean Marine Science 7(1): 87-118.

UNEP-MAP-RAC/SPA, 2008. Impact du Changement Climatique sur la Biodiversité en Mer Méditerranée, RAC/SPA.

Valenti, D., G. Denaro, A. La Cognata, B. Spagnolo, A. Bonanno, G. Basilone, S. Mazzola, S. Zgozi \& S. Aronica, 2012. Picophytoplankton dynamics in noisy marine environment. Acta Physica Polonica B 43(5): 1227-1240.

Valenti, D., G. Denaro, R. Ferreri, S. Genovese, S. Aronica, S. Mazzola, A. Bonanno, G. Basilone \& B. Spagnolo, 2017. Spatio-temporal dynamics of a planktonic system and chlorophyll distribution in a 2D spatial domain: matching model and data. Scientific Reports 7(1): 220.

Zarrad, R., F. Alemany, O. Jarboui, H. Missaoui \& A. Garcia, 2018. Spawning habitats of two small pelagic species (Engraulis encrasicolus and Sardinella aurita) in the Gulf of Gabés (Central Mediterranean). Hydrobiologia. https:// doi.org/10.1007/s10750-017-3301-5 (this issue).

Zenetos, A., S. Gofas, C. Morri, A. Rosso, D. Violanti, J. E. García Raso, M. E. Çinar, A. Almogi-Labin, A. S. Ates, E. Azzurro, E. Ballesteros, C. N. Bianchi, M. Bilecenoglu, M. C. Gambi, A. Giangrande, C. Gravili, O. HyamsKaphzan, P. K. Karachle, S. Katsanevakis, L. Lipej, F. Mastrototaro, F. Mineur, M. A. Pancucci-Papadopoulou, A. Ramos Esplá, C. Salas, G. San Martín, A. Sfriso, N. Streftaris \& M. Verlaque, 2012. Alien species in the Mediterranean Sea by 2012. A contribution to the application of European Union's Marine Strategy Framework Directive (MSFD). Part 2. Introduction trends and pathways. Mediterranean Marine Science 13(2): 328-352.

Zgozi, S., M. Barra, G. Basilone, M. Hamza, M. Assughayer, A. Nfate, G. Giacalone, I. Fontana, R. Mifsud, S. Goncharov, S. Popov, T. Bahri, M. Pulizzi, S. Genovese, L. Ceriola, S. Aronica, S. Mazzola \& A. Bonanno, 2018. Habitat suitability modelling for a key small pelagic fish species (Sardinella aurita) in the central Mediterranean sea. Hydrobiologia. https://doi.org/10.1007/s10750-017-32655 (this issue). 